\title{
Human Rights in the Age of Pandemics
}

\author{
Ibrahim Kaya ${ }^{1, *}$
}

\author{
${ }^{1}$ Anadolu University and Istanbul University Faculty of Law, Turkey \\ *Corresponding author. Email: kayai@hotmail.com
}

\begin{abstract}
Covid-19, which has been declared as a pandemic by the World Health Organization (WHO), is having very important impacts at the global level. By definition a pandemic concerns all states and therefore a close co-operation between states is essential to combat it in an adequate manner. States, sometimes unilaterally and sometimes collectively, are taking measures against the spread of the pandemic. Both international law and national laws also set out important rules for states to combat pandemics. The measures taken by states range from announcing simple cautions to total restrictions on the movement of people and even forced lock down, both for individuals and communities. States surely may take the necessary measures to maintain public health and the lives of individuals. Furthermore, it can be said that they are obliged to do so. On the other hand, due to the principle of rule of law, states are required to act in accordance with legal requirements including due process and human rights obligations. However, the effects of various legal measures taken by states in the struggle against Covid-19 pandemic raise some concerns on the basis of international regulations and domestic rules. These legal measures are closely related with certain rights protected under international human rights conventions, of which many states are parties. Consequently, they have already become a matter of dispute in many countries and there are clear signs that this dispute would evolve into a judicial question before international and national judicial authorities. This paper aims to examine the legality of the Covid-19 measures. To this end, first various international legal instruments will be analysed to find out the limits within which states can take and implement their measures in case of public emergencies. These will include global conventions such as the Covenant on Civil and Political Rights, the Covenant on Economic, Social and Cultural Rights and regional ones such as the European Convention on Human Rights and American Convention on Human Rights. Then, the World Health Organization's legal instruments that were drafted for the prevention of pandemics will be assessed in terms of human rights law. Finally, a discussion on the Covid-19 measures and human rights will be made.
\end{abstract}

Keywords: Covid-19, Human Rights, Pandemic, International Law, State Practice.

\section{BACKGROUND}

Covid-19, which has been declared a pandemic by the World Health Organization (WHO), has global and national effects [1]. It is also possible to point out that the measures taken in the context of combating the pandemic, especially with security concerns, may have an impact on human rights. There is a serious concern that measures such as curfew, quarantine, restriction of travel, closing of various workplaces, sharing some personal data that may be related to the disease, and tracking people with mobile applications will have some consequences against human rights [2].
International human rights law, whose development gained momentum with the Universal Declaration of Human Rights by the United Nations (UN) in 1948, brought binding rules for states with both universal and regional international treaties concluded, especially the twin covenants dated 1966. It was understood that the early original treaties were not sufficient to provide rights over time, and then, by additional protocols and newly signed treaties, human rights have continuously improved [3]. In this process, many human rights, especially the rights to life and health, have been guaranteed by international treaties that regulate the issue. In addition, various international mechanisms have been established 
to realize these rights at international level. For this purpose, while the European Convention on Human Rights (ECHR) was establishing the European Court of Human Rights as an international judicial body, separate application and monitoring mechanisms for UN twin covenants were also created [4].

It is very well known that measures to be taken in combating pandemics must also comply with the international obligations of the states, especially human rights. As a matter of fact, many states have recognized these rights in their domestic law. The Covid-19 measures must also comply with the rule of law. Otherwise, the risk of weakening the democratic society may arise due to the abuse of the measures taken, and state responsibility may arise for violating a number of rights before both international and domestic law [5]. Therefore, it is very urgent and important to examine the measures taken in the fight against the Covid-19 pandemic in terms of international human rights law, to determine the legality of state practices.

\section{RESTRICTION AND DEROGATION OF HUMAN RIGHTS IN TIMES OF EMERGENCY}

Throughout the history of humanity, societies have faced various threats and took the necessary precautions to eliminate them. Indeed, the constitutions of many states allow them to take measures in case of emergencies. For example Turkish Constitution states that: "In times of war, mobilization, a state of emergency, the exercise of fundamental rights and freedoms may be partially or entirely suspended, or measures derogating the guarantees embodied in the Constitution may be taken to the extent required by the exigencies of the situation, as long as obligations under international law are not violated" [6].

In this respect, international human rights treaties also include similar provisions and allow states parties to take measures within a certain framework through the legal exception procedure called "derogation" in some special cases. For example, Article 15 of the ECHR states that "In time of war or other public emergency threatening the life of the nation any High Contracting Party may take measures derogating from its obligations under this Convention to the extent strictly required by the exigencies of the situation, provided that such measures are not inconsistent with its other obligations under international law." Similarly, another regional human rights treaty, the American Convention on Human Rights, recognizes the right to suspend by Article 27. Not only regional treaties, but also the UN International Covenant on Civil and Political Rights, which is a universal human rights treaty, allows the limitation of obligations stating that "In time of public emergency which threatens the life of the nation and the existence of which is officially proclaimed, the States Parties to the present Covenant may take measures derogating from their obligations under the present Covenant to the extent strictly required by the exigencies of the situation, provided that such measures are not inconsistent with their other obligations under international law and do not involve discrimination solely on the ground of race, colour, sex, language, religion or social origin." [7]. However, the measures to be taken in accordance with such a procedure must comply with the principles of necessity, legitimacy and proportionality [8]. In addition, some rights called core rights are not subject to these exceptions, and they must be provided under all circumstances.

In this context, some states have preferred to use the derogation option while others imposed limitations on rights without a general derogation to fight the Covid-19 pandemic. States falling in the latter group have used limitation clauses contained in international agreements. For example, Article 2 of the Additional Protocol IV to the ECHR, that recognizes the freedom of movement, allows a limitation as long as they are "in accordance with law and are necessary in a democratic society in the interests of national security or public safety, for the maintenance of ordre public, for the prevention of crime, for the protection of health or morals, or for the protection of the rights and freedoms of others." This article enables states to limit the freedom of movement lawfully for public safety and protection of health.

\section{WORLD HEALTH ORGANIZATION AND HUMAN RIGHTS}

Taking international measures to combat epidemics goes back before the establishment of the WHO. The World Health Organization Founding Treaty was adopted at the International Health Conference held in July 1946 and this text was signed by 61 states and ratified. After the WHO was established, previous organizations either came under its roof or ceased to exist. Thus, a single international organization with authority in this field has been formed. The WHO has played an important role in combating epidemics by issuing international health regulations.

The purpose of the Organization is expressed in Article 1 of the Founding Treaty as "to bring all nations to the highest possible health level". For this purpose, a number of functions to be fulfilled are stated in Article 2. The Organization's main bodies are the World Health Assembly, the Executive Council and the Secretariat. In addition to these bodies, there 
are regional committees and offices affiliated with the Organization. One of the most important normative powers of the Assembly is to make conventions and agreements that establish international rules on health. After the texts of these are accepted by this body by a two-thirds majority, they enter into force as the legally binding instruments by the member states in accordance with their constitutional procedures.

Another normative function of the Assembly is the authority to make regulations in certain fields. Regulations adopted by the Assembly by majority vote automatically become binding on all member states, except those states that reject or make reservations, within a certain period of time. The first regulation adopted by the Assembly was the WHO Regulation on Terminology (Nomenclature) on Diseases and Causes of Death, adopted in 1948. The most important of the regulations adopted by the Assembly to this day is the International Health Regulations, which were first adopted in 1951 and amended in 1969 and 2005. The current regulation was adopted on 23 May 2005 and entered into force on 15 June 2007.

In this respect, the purpose and scope of the International Health Regulations (IHR) "are to prevent, protect against, control and provide a public health response to the international spread of disease in ways that are commensurate with and restricted to public health risks, and which avoid unnecessary interference with international traffic and trade."[9]. No restrictive list is given here, and all outbreaks with international spread have been accepted within the scope.

The WHO Director-General has to decide whether a public health emergency of international concern (PHEIC) has occurred on the basis of information from the state in which an event is taking place. If it comes to the view that a public health emergency of this nature has arisen, it will consult with the relevant state and call the Emergency Committee for a meeting. The Committee will convey its opinions to the General Director in order to make the final decision. The Director-General, in conjunction with the comments of the Committee, "... shall communicate to States Parties the determination and the termination of a public health emergency of international concern, any health measure taken by the State Party concerned, any temporary recommendation, and the modification, extension and termination of such recommendations" [10].

If a PHEIC is found to be happening, the DirectorGeneral may issue temporary recommendations [11]. The recommendations may include "health measures to be implemented by the State Party experiencing the public health emergency of international concern, or by other States Parties, regarding persons, baggage, cargo, containers, conveyances, goods and/or postal parcels to prevent or reduce the international spread of disease and avoid unnecessary interference with international traffic."[12].

Temporary recommendations can be terminated at any time. If they are not terminated, they will expire automatically three months after they were published. It is also possible to modify the recommendations or extend them quarterly [13]. Although they are called "recommendations", it is envisaged that the health measures taken in accordance with the Regulations will be "initiated and completed without delay, and implemented in a transparent and non-discriminatory manner" [14].

\section{COVID-19 AND HUMAN RIGHTS}

China reported Covid-19 to the WHO on 31December 2019, isolated the virus on 7 January 2020, and shared its genetic sequence with WHO on 12 January. [15] Unlike the first meeting, the Emergency Committee, which convened for the second time on 30 January 2020, has decided that the incident now meets the conditions required to be declared a PHEIC and the temporary measures should be taken. Thereupon, the Director-General declared the Covid-19 outbreak as a PHEIC and temporary recommendations were made [16].

The Emergency Committee abstained to call for restrictions at its two meetings. Finally, at its third meeting on 30 April 2020, the Emergency Committee decided to update its recommendations on appropriate action on travel and trade. Accordingly, the Organization also mentioned the establishment of a balance between the expected benefits from these measures and undesirable results. These measures include observation and examination to be carried out on entry and exit, training passengers to exhibit responsible travel behavior, following contacts, isolation and quarantine. It was also emphasized that the WHO will continue to work with states in order to enable compulsory travel in the fight against pandemic, humanitarian aid, return to the country and freight transportation.

In state practice, some states have introduced bans on freedom of speech and right to information as some governments enforced early censorship to suppress information about COVID-19 and the dangers it poses to public health [17]. Freedom of assembly and religion are also said to be restricted. Also refugees and asylum seekers as well as the disadvantaged have negatively affected by the Covid-19 measures. Not only civil and political rights but also social and economic rights have been threatened by the Covid-19 measures. In many countries an important portion of 
the population faced unemployment and loss of labour rights [18].

\section{CONCLUSION}

The current pandemic of Covid-19 has created a lot of problems worldwide from economy to legal issues. The WHO's IHR are an international legal instrument binding all the member states to prevent and respond to public health risks that have the potential to cross borders [19]. In the IHR, one of the key issues is to strike the right balance between controlling the spread of the disease and to keep the international supply chain open. Another key point in the IHR is the respect for human rights while combating the pandemic. Although countries have right to take adequate measures to combat the pandemic, all the measures are required to comply with their international human rights obligations. Otherwise, state responsibility may arise.

* A plenary paper presented in the International Conference on Law and Human Rights under the theme Reimagining the Vision on Law and Human Rights, organised by Research and Development Agency for Law and Human Rights, Ministry of Law and Human Rights \& Faculty of Law, Syiah Kuala University, Aceh, Indonesia, on 26-27 October 2020.

\section{REFERENCES}

[1] Beigbeder, Yves 2013. "World Health Organization", Max Planck Encyclopedias of International Law; Telesetsky, Anastasia 2020, "International Governance of Global Health Pandemics" https://www.asil.org/insights/volume/24/issue/3/i nternational-governance-global-healthpandemics 16 June 2020; Eccleston-Turner, Mark 2020, "Declaration of a Public Health Emergency of International Concern in International Law', http://opiniojuris.org/2020/03/31/covid-19symposium-the-declaration-of-a-public-healthemergency-of-international-concern-ininternational-law/ 10 June 2020.

[2] Bogdandy, Armin von \& Villarreal, Pedro A, "International Law on Pandemic Response: A First Stocktaking in Light of the Coronavirus Crisis", MPIL Research Paper Series No 202007.

[3] Shaw, Malcolm 2017, International Law (7th ed.), Cambridge: Cambridge University Press.
[4] Acer, Yucel \& Kaya, İbrahim 2020, International Law (10th ed.), Ankara: Seckin.

[5] Bergkamp, Lucas 2020. "State Liability for Failure to Control the COVID-19 Epidemic", International and Dutch Law' European Journal of Risk Regulation 11(2): 343-349; De Herdt, Sandrine 2020, "A Reference to the ICJ for an Advisory Opinion over COVID-19"; Coco, Antonio \& de Souza Talita 2020, "Due Diligence and COVID-19: States' Duties to Prevent and Halt the Coronavirus Outbreak' https://www.ejiltalk.org/part-i-due-diligenceand-covid-19-states-duties-to-prevent-and-haltthe-coronavirus-outbreak/ 15 June 2020.

[6] Article 15.

[7] Article 4.

[8] UN Commission, 1984

[9] Article 2.

[10] Article 49/6.

[11] Article 15/1

[12] Article 15/2.

[13] Article 15/3.

[14] Article 42.

[15] www.who.int

[16] www.who.int

[17] www.amnesty.org

[18] www.ilo.org

[19] Kaya, Ibrahim \& Simsek. G. Engin "World Health Organization and International Health Regulations: The COVID-19 Case and Combating Epidemics Under International Law" Vol. 78, No. 2, 2020. 